\title{
"Modified Unified Method" of Carp Capture
}

\section{Background}

Populations of Hypophthalmichthys molitrix (silver carp) and Hypophthalmichthys nobilis (bighead carp), (together referred to herein as "bigheaded carp") have increased exponentially in the greater Mississippi River Basin (Kolar and others, 2007). Detrimental effects on native fish and economically important fisheries have occurred where these filter-feeding fish are abundant (Chick and others, 2020). The Unified Method, a harvest technique developed in China for bigheaded carp in flood plain lakes, uses herding techniques and a variety of nets to drive bigheaded carp and concentrate them into an area where they can be easily harvested ( $\mathrm{Li}$ and $\mathrm{Xu}, 1995)$.

\section{Adaptation for North America}

In China, lakes encompassing thousands of hectares are used as private aquaculture facilities (Chapman and others, 2016), and they are harvested with the Unified Method. Without the constraints of public access and competing interests, Chinese managers can harvest as much as 85 percent of bigheaded carp.

A Unified Method effort in China would typically last for 2-3 months. Infrastructure and nets can be left in position as desired because there are no other users of the lake. There are no restrictions on the harvest of nontarget species.

The U.S. Geological Survey (USGS) is adapting the Chinese Unified Method concepts to be consistent with North American financial, societal, and environmental conditions. We have modified these techniques and incorporated modern technology to reduce the time and expense of Unified Methods and to allow them to be used in public waters. Thus, the operations in North America are often described as the "Modified Unified Method" (MUM). The USGS is studying and refining MUM methods to provide stakeholders with efficient, validated, and environmentally friendly methods for carp removal.

\section{Location and Timing}

MUM operations are usually performed in the winter because low water temperatures decrease fish activity, including most jumping. In warm water conditions, silver carp leap over block nets and escape capture. The MUM is usually performed in water bodies with little current that are shallow enough for block nets to reach from top to bottom, but new techniques may be developed for other water bodies.

\section{Herding Techniques}

Block nets are used to create compartments or "cells" from which the fish can be driven. The USGS uses electrofishing boats

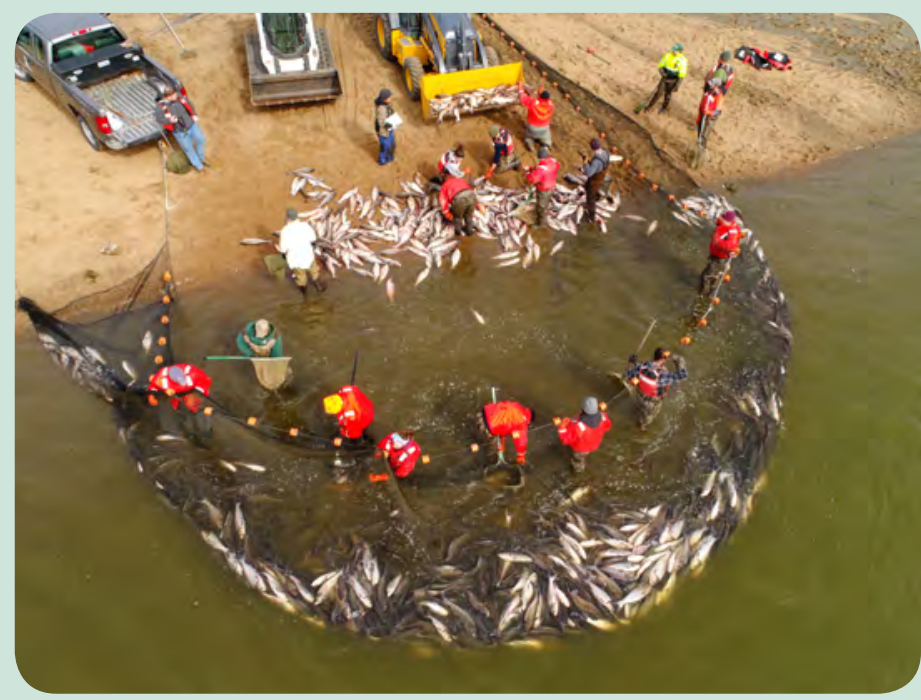

Seining of fish has been the typical final step of a MUM operation in the United States. Photograph by USGS.

and boats outfitted with underwater speakers to herd carp from each cell. When a cell is cleared, another net is used to close the cell and prevent the fish from returning. This process is repeated one cell at a time, gradually reducing the area available to the carp and concentrating the fish into a harvest area. Native game fish do not seem to respond in the same way, preferring to hide, rather than run, from the sound stimulus. For this reason, few game fish are typically caught.

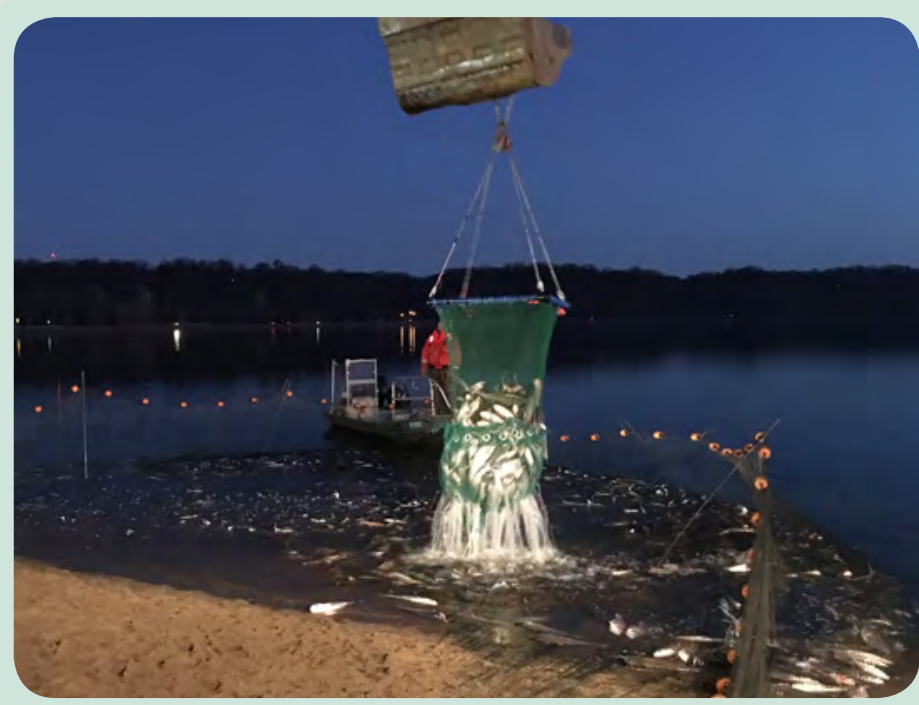

Harvesting of bigheaded carp using a brailer. Photograph by USGS. 


\section{Adaptations}

The USGS uses side-scan sound navigation ranging (sonar) to determine when a cell is cleared and to determine the location of the school of carp when deploying a seine. The use of sonar greatly improves efficiency over traditional Chinese methods. Underwater speakers are not used in China; electricity is sometimes used, but the USGS is developing improved methods for herding fish with electricity. In China, trap nets are used to harvest carp over months, whereas the harvest portion of a MUM operation in North America usually is done by seining the fish after they have been concentrated. A long net is laid around the school of carp and the net is slowly pulled to shore. A MUM harvest can thus sometimes be completed in less than a day. These adaptations have been highly successful. For example, in 2018, the USGS collaborated with the State of Missouri to remove 240,000 pounds of carp from the 300-acre Creve Coeur Lake in St. Louis, Missouri. With these modifications, the method becomes more reasonable for application for bigheaded carp capture in the United States; however, these methods are still new to the United States and additional research is needed to further increase efficiency of MUM operations.

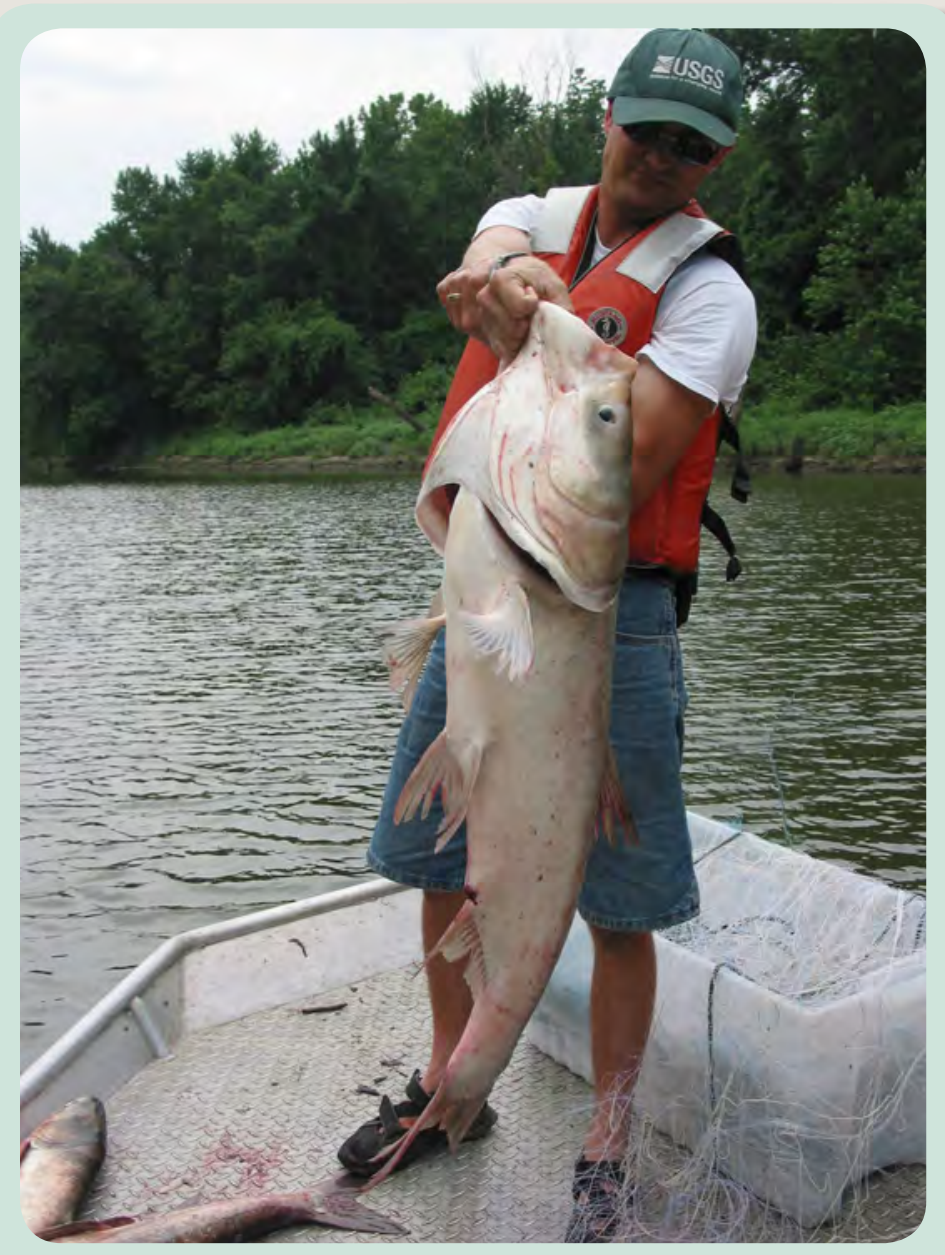

A USGS scientist with a large bigheaded carp. Photograph by USGS.

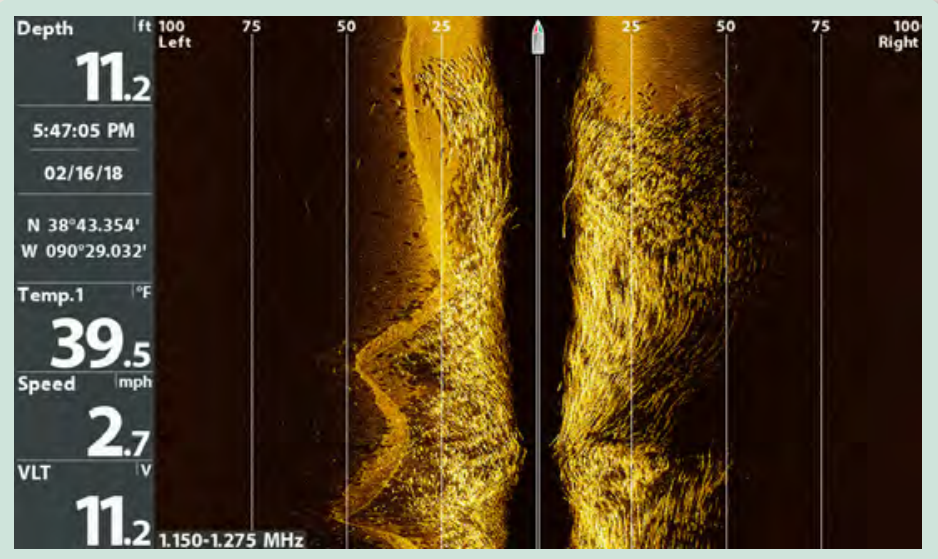

Sidescan image from a boat that has passed over a school of thousands of bigheaded carp concentrated by a MUM operation. The block net retaining the fish is visible to the left of the boat. The dark area in the center is an area not imaged by sidescan. Fish that are moving in the same direction as the boat appear as long lines. Image by USGS.

\section{References Cited}

Chapman, D.C., Chen, D., Hoover, J.J., Du, H., Phelps, Q.E., Shen, L., Wang, C., Wei, Q., and Zhang, H., 2016, Bigheaded carps of the Yangtze and Mississippi Rivers-Biology, status, and management, in Chen, Y., Chapman, D.C., Jackson, J.R., Chen, D., Li, Z., Killgore, K.J., Phelps, Q., and Eggleston, M.A., eds., Fishery Resources, Environment, and Conservation in the Mississippi and Yangtze (Changjiang) River Basins: American Fisheries Society (Bethesda, Maryland), p. 113-126.

Chick, J.H., Gibson-Reinemer, D.K, Soeken-Gitinger, L.S., and Casper, A.F., 2020, Invasive silver carp is empirically linked to declines of native sport fish in the Upper Mississippi River System: Biological Invasions, v. 22, no. 2, p. 723-734.

Kolar, C.S., Chapman, D.C., Courtenay, W.R., Jr., Housel, C.M., Williams, J.D., and Jennings, D.P., 2007, Bigheaded carps-A biological synopsis and risk assessment: American Fisheries Society (Bethesda, Maryland), Special Publication 33, 204 p.

Li, S., and Xu, S., 1995, Culture and capture of fish in Chinese reservoirs: Penang, Malaysia, International Development Research Centre, 140 p.

For more information about this publication, contact:

Director, USGS Columbia Environmental Research Center

4200 New Haven Road

Columbia, MO 65201

573-875-5399

For additional information, visit: https://www.usgs.gov/centers/cerc

Publishing support provided by the

Rolla Publishing Service Center 